CRYSTALLOGRAPHIC COMMUNICATIONS

ISSN 2056-9890

Received 14 April 2021

Accepted 22 April 2021

Edited by S. Parkin, University of Kentucky, USA

Keywords: crystal structure; oxidotellurate(IV); oxidoarsenate $(\mathrm{V})$; hydrogen bonding; lone pair electrons; stereochemical activity.

CCDC reference: 2079463

Supporting information: this article has supporting information at journals.iucr.org/e

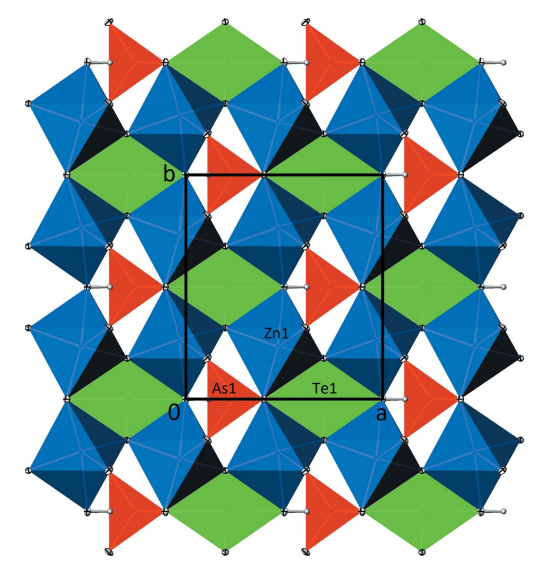

OPEN ○ ACCESS

\section{Crystal structure of $\mathrm{Zn}_{2}\left(\mathrm{HTeO}_{3}\right)\left(\mathrm{AsO}_{4}\right)$}

\author{
Felix Eder* and Matthias Weil
}

Institute for Chemical Technologies and Analytics, Division of Structural Chemistry, TU Wien, Getreidemarkt 9/164-SC, A-1060, Vienna, Austria. ${ }^{*}$ Correspondence e-mail: felix.eder@tuwien.ac.at

Single crystals of $\mathrm{Zn}_{2}\left(\mathrm{HTeO}_{3}\right)\left(\mathrm{AsO}_{4}\right)$, dizinc(II) hydroxidodioxidotellurate(IV) oxidoarsenate $(\mathrm{V})$, were obtained as one of the by-products in a hydrothermal reaction between $\mathrm{Zn}\left(\mathrm{NO}_{3}\right)_{2} \cdot 6 \mathrm{H}_{2} \mathrm{O}, \mathrm{TeO}_{2}, \mathrm{H}_{3} \mathrm{AsO}_{4}$ and $\mathrm{NH}_{3}$ in molar ratios of 2:1:2:10 at $483 \mathrm{~K}$ for seven days. The asymmetric unit of $\mathrm{Zn}_{2}\left(\mathrm{HTeO}_{3}\right)\left(\mathrm{AsO}_{4}\right)$ contains one Te (site symmetry $m$ ), one As $(m)$, one $\mathrm{Zn}(1)$, five $\mathrm{O}$ (three $m$, two 1) and one $\mathrm{H}(m)$ site. The $\mathrm{Zn}^{\mathrm{II}}$ atom exhibits a coordination number of 5 and is coordinated by four oxygen atoms and a hydroxide group, forming a distorted trigonal bipyramid. The hydroxide ion is positioned at a significantly larger distance on one of the axial positions of the bipyramid. The $\left[\mathrm{ZnO}_{4} \mathrm{OH}\right]$ polyhedra are connected to each other by corner-sharing to form ${ }_{\infty}^{2}\left[\mathrm{ZnO}_{3 / 2}(\mathrm{OH})_{1 / 2} \mathrm{O}_{1 / 1}\right]$ layers extending parallel to (001). The $\mathrm{Te}^{\mathrm{IV}}$ atom is coordinated by three oxygen atoms and a hydroxide group in a one-sided manner in the shape of a bisphenoid, revealing stereochemical activity of its $5 s^{2}$ electron lone pair. The $\mathrm{As}^{\mathrm{V}}$ atom is coordinated by four oxygen atoms to form the tetrahedral oxidoarsenate $(\mathrm{V})$ anion. By corner-sharing, $\left[\mathrm{TeO}_{3} \mathrm{OH}\right]$ and $\left[\mathrm{AsO}_{4}\right]$ groups link adjacent ${ }_{\infty}^{2}\left[\mathrm{ZnO}_{3 / 2}(\mathrm{OH})_{1 / 2} \mathrm{O}_{1 / 1}\right]$ layers along [001] into a three-dimensional framework structure.

\section{Chemical context}

Only a few elements have such a diverse crystal chemistry as tellurium, especially in its +IV oxidation state. This can be attributed to the stereochemically active non-bonding $5 s^{2}$ electron pair of $\mathrm{Te}^{\mathrm{IV}}$ (Galy et al., 1975) that has a similar space requirement as coordinating ligands and therefore often results in one-sided and low-symmetry coordination spheres around $\mathrm{Te}^{\mathrm{IV}}$ atoms. An extensive review of the rich crystal chemistry of oxidotellurates(IV) was published recently by Christy et al. (2016).

The peculiar crystal chemistry of $\mathrm{Te}^{\mathrm{IV}}$ makes it an interesting building block in the search for new compounds with crystal structures lacking inversion symmetry. As a prerequisite, a compound must be non-centrosymmetric in order to have ferro-, piezo- or pyroelectric properties or to possess non-linear optical properties (Ok et al., 2006). Another effect of the electron lone pair and its large space consumption is the frequent formation of open-framework structures in (transition) metal oxidotellurates(IV). Different structure units such as clusters, chains, layers or channels resulting from the presence of oxidotellurate(IV) anions are observed in various crystal structures (Stöger \& Weil, 2013). Introducing secondary anions into transition-metal oxidotellurates(IV) can lead to even more structural diversification. Over the past few years, several anions have been incorporated into metal or transition-metal oxidotellurates, viz. sulfates [e.g. $\mathrm{Cd}_{4}\left(\mathrm{SO}_{4}\right)\left(\mathrm{TeO}_{3}\right)_{3}$; Weil \& Shirkhanlou, 2017a], selenates [e.g. $\mathrm{Zn}_{2}\left(\mathrm{SeO}_{4}\right)\left(\mathrm{TeO}_{3}\right)$; Weil \& Shirkhanlou, 2017b], carbonates 
[e.g. $\mathrm{Pb}_{5}\left(\mathrm{SeO}_{4}\right)_{2}\left(\mathrm{TeO}_{4}\right)\left(\mathrm{CO}_{3}\right)$; Weil \& Shirkhanlou, 2017c], nitrates [e.g. $\mathrm{Ca}_{6} \mathrm{Te}_{5} \mathrm{O}_{15}\left(\mathrm{NO}_{3}\right)_{2}$; Stöger \& Weil, 2013], phosphates [e.g. $\mathrm{Co}_{3} \mathrm{Te}_{2} \mathrm{O}_{2}\left(\mathrm{PO}_{4}\right)_{2}(\mathrm{OH})_{4}$; Zimmermann et al., 2011] or, very recently, arsenates $\left[\mathrm{Cu}_{5}\left(\mathrm{TeO}_{3}\right)_{2}\left(\mathrm{AsO}_{4}\right)_{2}\right.$; Missen et al., 2020]. Crystals of $\mathrm{Cu}_{5}\left(\mathrm{TeO}_{3}\right)_{2}\left(\mathrm{AsO}_{4}\right)_{2}$ have been grown by a chemical transport reaction (Binnewies et al., 2012), starting from $\mathrm{CuO}, \mathrm{TeO}_{2}$ and $\mathrm{As}_{2} \mathrm{O}_{5}$ at temperatures of $1023 \mathrm{~K}$ (source) and $953 \mathrm{~K}$ (sink). The title compound, $\mathrm{Zn}_{2}\left(\mathrm{HTeO}_{3}\right)\left(\mathrm{AsO}_{4}\right)$, however, was obtained at much milder temperatures $(483 \mathrm{~K})$ under hydrothermal conditions.

\section{Structural commentary}

The asymmetric unit of $\mathrm{Zn}_{2}\left(\mathrm{HTeO}_{3}\right)\left(\mathrm{AsO}_{4}\right)$ contains one $\mathrm{Te}$, one $\mathrm{As}$, one $\mathrm{Zn}$, one $\mathrm{H}$ and five $\mathrm{O}$ atoms located either on a special position with site symmetry $m$ (Wyckoff position $2 a$; Te1, As1, O3, O4, O5, H1) or on general positions (Wyckoff position $4 b$; $\mathrm{Zn} 1, \mathrm{O} 1, \mathrm{O} 2)$. Selected bond lengths are collated in Table 1.

The zinc cation $(\mathrm{Zn} 1)$ is coordinated by five oxygen atoms with one (O3, as part of the hydroxy group) being at a significantly longer distance [2.3259 (18) $\AA$ ] than the other four [1.979 (3)-2.0486 (16) $\AA$ ]. The resulting polyhedron has the shape of a distorted trigonal bipyramid, with the remote $\mathrm{O} 3$ site occupying one of the axial positions and the equatorial positions being slightly tilted towards it (Fig. 1). The geometry index $\tau_{5}$ (Addison et al., 1984), which is 0 for an ideal square pyramid and 1 for an ideal trigonal bipyramid, amounts to 0.665 for the $\left[\mathrm{ZnO}_{4} \mathrm{OH}\right]$ polyhedron. The $\left[\mathrm{ZnO}_{4} \mathrm{OH}\right]$ polyhedra are connected to each other by sharing four corners with neighbouring polyhedra to form ${ }_{\infty}^{2}\left[\mathrm{ZnO}_{3 / 2}(\mathrm{OH})_{1 / 2} \mathrm{O}_{1 / 1}\right]$ layers extending parallel to (001). The bond-valence sum

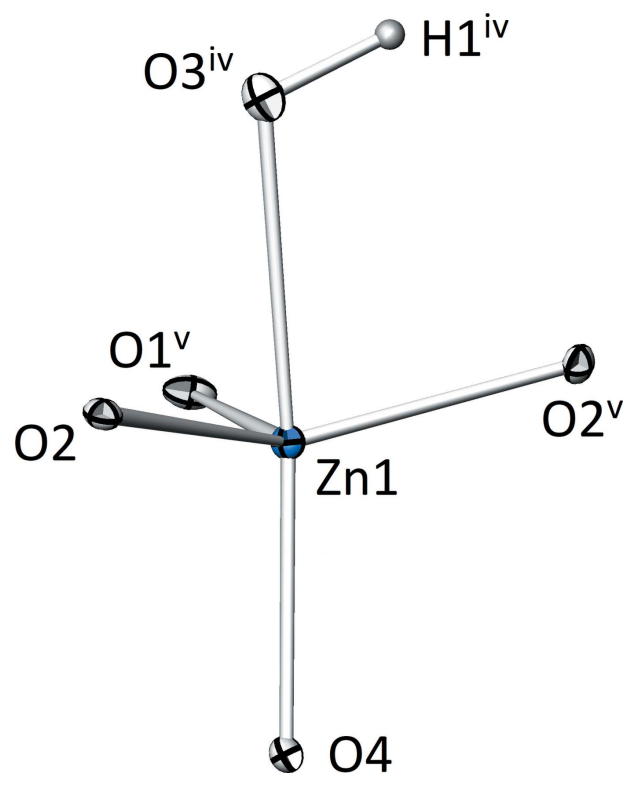

Figure 1

The distorted trigonal-bipyramidal $\left[\mathrm{ZnO}_{4} \mathrm{OH}\right]$ polyhedron in the crystal structure of $\mathrm{Zn}_{2}\left(\mathrm{HTeO}_{3}\right)\left(\mathrm{AsO}_{4}\right)$. Displacement ellipsoids are drawn at the $90 \%$ probability level. Symmetry codes refer to Table 1 .
Table 1

Selected bond lengths $(\AA)$.

\begin{tabular}{llll}
\hline $\mathrm{Te} 1-\mathrm{O} 2^{\mathrm{i}}$ & $1.880(2)$ & $\mathrm{As} 1-\mathrm{O} 5$ & $1.716(3)$ \\
$\mathrm{Te} 1-\mathrm{O}^{\mathrm{ii}}$ & $1.880(2)$ & $\mathrm{Zn} 1-\mathrm{O} 2^{\mathrm{v}}$ & $1.979(3)$ \\
$\mathrm{Te} 1-\mathrm{O} 3^{\mathrm{iii}}$ & $2.070(4)$ & $\mathrm{Zn} 1-\mathrm{O}^{\mathrm{v}}$ & $1.987(3)$ \\
$\mathrm{Te} 1-\mathrm{O} 5$ & $2.131(4)$ & $\mathrm{Zn} 1-\mathrm{O} 2$ & $1.993(3)$ \\
$\mathrm{As} 1-\mathrm{O} 1^{\mathrm{iv}}$ & $1.673(2)$ & $\mathrm{Zn} 1-\mathrm{O} 4$ & $2.0486(16)$ \\
As1-O1 & $1.673(2)$ & $\mathrm{Zn} 1-3^{\mathrm{vi}}$ & $2.3259(18)$ \\
As1-O4 & $1.709(3)$ & & \\
\hline
\end{tabular}

Symmetry codes: (i) $x+\frac{1}{2},-y+\frac{1}{2}, z+1$; (ii) $x+\frac{1}{2}, y-\frac{1}{2}, z+1$; (iii) $x+1, y, z+1$; (iv) $x,-y, z$; (v) $x+\frac{1}{2},-y+\frac{1}{2}, z$; (vi) $x+\frac{1}{2}, y+\frac{1}{2}, z$.

(BVS; Brown, 2002) of $\mathrm{Zn} 1$ was calculated to be 1.98 valence units (v.u.) using the values of Brese \& O'Keeffe (1991).

The tellurium(IV) atom (Te1) is coordinated by four oxygen atoms with bond lengths in the range 1.880 (2)-2.131 (4) $\AA$. The BVS of Te1 is 4.02 v.u. using the values of Brese \& O'Keeffe (1991) for calculation. With the revised bondvalence values by Mills \& Christy (2013), a lower BVS of 3.86 v.u. was calculated under consideration of the four nearest oxygen atoms. However, the BVS increases to 4.03 v.u. if all oxygen atoms within a distance of up to $3.5 \AA$ are accounted for, as is suggested by Mills \& Christy (2013). The resulting $\left[\mathrm{TeO}_{3} \mathrm{OH}\right]$ coordination polyhedron is a bisphenoid. Under consideration of the space requirement of the $5 s^{2}$ electron lone pair, the corresponding $\left[\Psi \mathrm{TeO}_{3} \mathrm{OH}\right]$ polyhedron has the shape of a distorted trigonal bipyramid with the non-bonding electron pair occupying an equatorial position (Fig. 2). The geometry index $\tau_{5}$ of the $\left[\Psi \mathrm{TeO}_{3} \mathrm{OH}\right]$ polyhedron is 0.413 . The LPLoc software (Hamani et al., 2020) revealed the position of the electron lone pair with resulting fractional coordinates of $x$ $=0.7781, y=0, z=0.5519$. The radius of the electron lone pair was calculated to be $1.32 \AA$ with a distance of $1.680 \AA$ from the

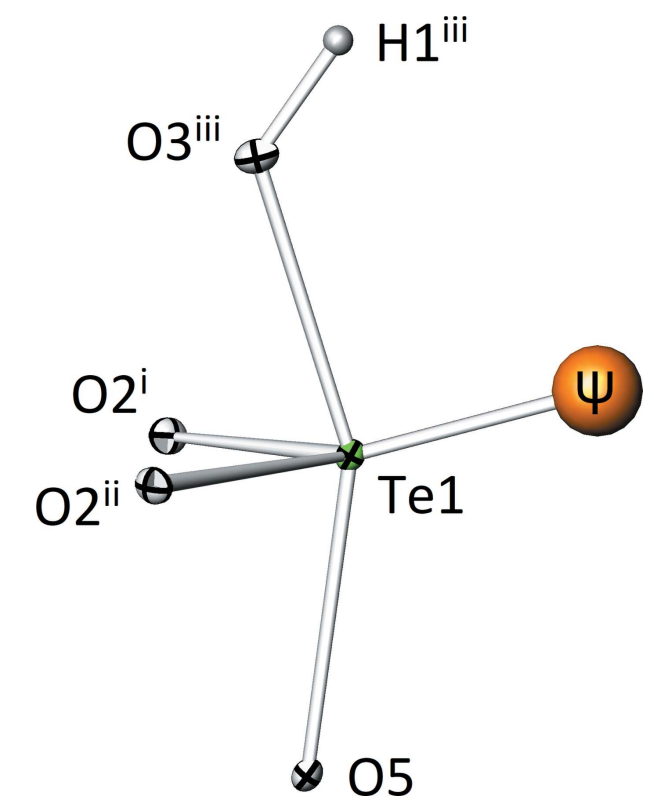

Figure 2

The bisphenoidal $\left[\mathrm{TeO}_{3} \mathrm{OH}\right]$ polyhedron in the crystal structure of $\mathrm{Zn}_{2}\left(\mathrm{HTeO}_{3}\right)\left(\mathrm{AsO}_{4}\right)$. Displacement ellipsoids are drawn at the $90 \%$ probability level. The $5 s^{2}$ electron lone pair $(\Psi$, orange) is drawn with an arbitrary radius of $0.2 \AA$. Symmetry codes refer to Table 1 . 
Table 2

Hydrogen-bond geometry $\left(\AA,^{\circ}\right)$.

\begin{tabular}{lllll}
\hline$D-\mathrm{H} \cdots A$ & $D-\mathrm{H}$ & $\mathrm{H} \cdots A$ & $D \cdots A$ & $D-\mathrm{H} \cdots A$ \\
\hline $\mathrm{O} 3-\mathrm{H} 1 \cdots \mathrm{O}^{\text {vii }}$ & $0.94(9)$ & $2.28(9)$ & $3.213(5)$ & $179(7)$ \\
\hline
\end{tabular}

Symmetry code: (vii) $x, y, z-1$.

Te1 position. The oxygen atom (O3) of the hydroxy group is located on an axial position of the $\left[\Psi \mathrm{TeO}_{3} \mathrm{OH}\right]$ polyhedron. Its hydrogen atom is directed to the $\mathrm{O} 5$ site, forming a weak

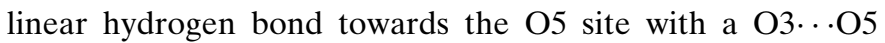
distance of 3.213 (5) $\AA$ (Table 2). It is remarkable that the hydrogen atom is located on the oxidotellurate(IV) unit instead of the oxidoarsenate $(\mathrm{V})$ anion given that for $0.1-0.01$ $N$ solutions, the $\mathrm{p} K_{b}$ value of the $\left[\mathrm{AsO}_{4}\right]^{3-}$ anion is much smaller $(2.40$ at $291 \mathrm{~K})$ than that of the $\left[\mathrm{TeO}_{3}\right]^{2-}$ anion $(6.30$ at $298 \mathrm{~K}$ ) (Weast \& Astle, 1982). Even though the conditions during the hydrothermal experiment are far from the tabulated values, it is surprising that a difference in the equilibrium constants of almost four orders of magnitude was overridden in the resulting crystal. Nevertheless, as evidenced from a difference-Fourier map and BVS calculations (BVS without contribution of the $\mathrm{H}$ atom amounts to 1.15 v.u. for O3), the hydroxide group is located on the oxidotellurate(IV) unit.

The arsenic(V) atom (As1) is coordinated tetrahedrally by four oxygen atoms with distances in the range $1.673(2)-$

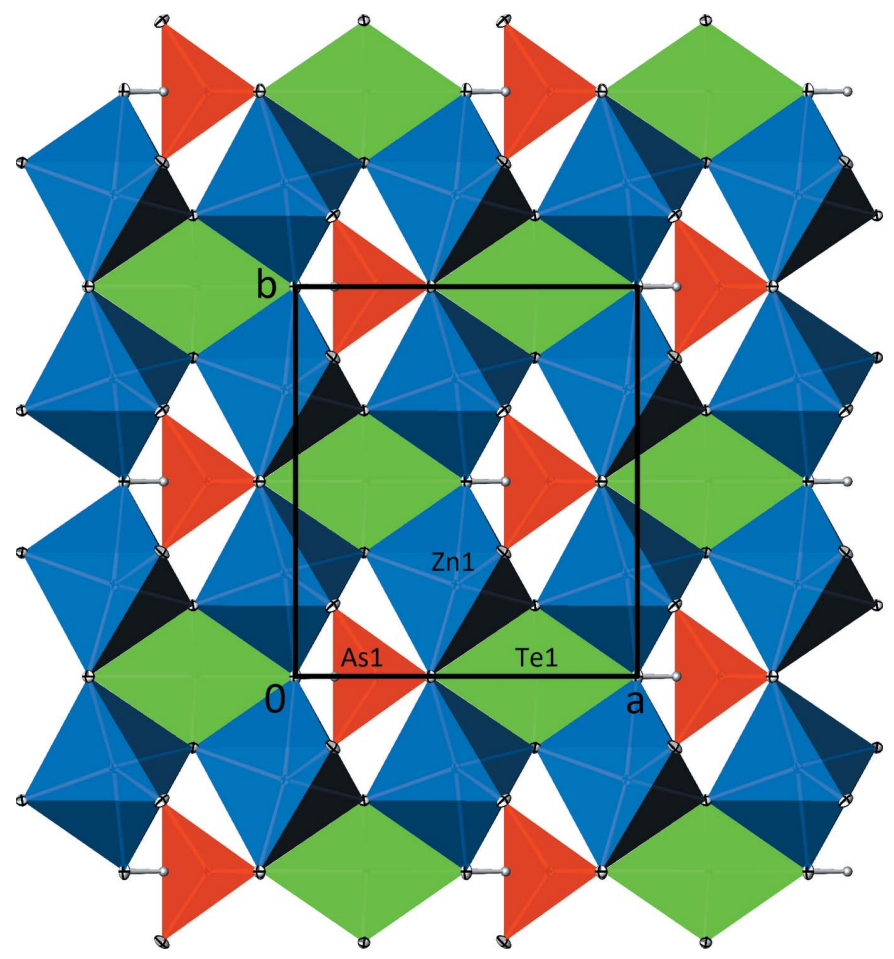

Figure 3

The crystal structure of $\mathrm{Zn}_{2}\left(\mathrm{HTeO}_{3}\right)\left(\mathrm{AsO}_{4}\right)$ in polyhedral representation, projected onto (001). $\left[\mathrm{ZnO}_{4} \mathrm{OH}\right]$ polyhedra are blue, $\left[\mathrm{TeO}_{3} \mathrm{OH}\right]$ polyhedra are green and $\left[\mathrm{AsO}_{4}\right]$ tetrahedra are red; $\mathrm{H}$ atoms are represented as grey spheres of arbitrary radius. Displacement ellipsoids are drawn at the $90 \%$ probability level.

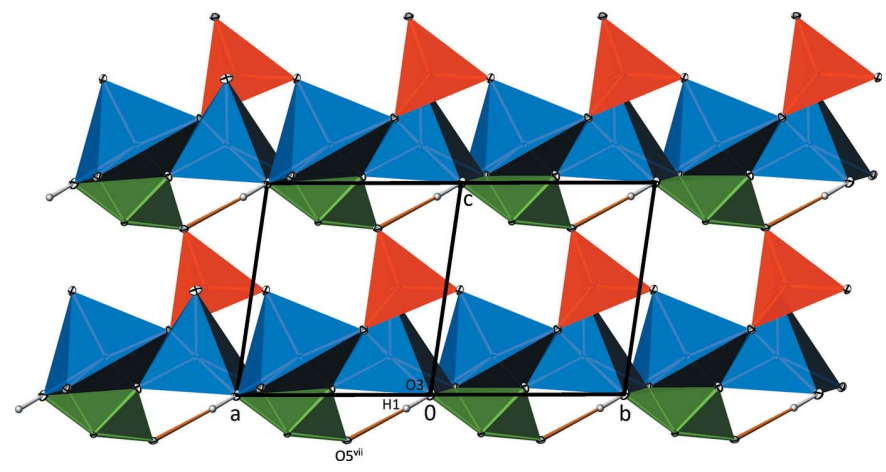

Figure 4

Channels in the crystal structure of $\mathrm{Zn}_{2}\left(\mathrm{HTeO}_{3}\right)\left(\mathrm{AsO}_{4}\right)$ running parallel to [110]. Colour codes and displacement ellipsoids are as in Fig. 3. O$\mathrm{H} \cdot \mathrm{O}$ hydrogen bonds are shown as orange lines.

1.716 (3) $\AA$. The mean As-O bond length of 1.693 (23) $\AA$ is slightly longer than those reported for $\mathrm{AsO}_{4}{ }^{3-}$ groups [1.667 (18) А̊; Schwendtner \& Kolitsch, 2019] or for oxidoarsenate groups in general (also including $\mathrm{As}-\mathrm{OH}$ bonds, with an overall mean of 1.687 (27) $\AA$; Gagné \& Hawthorne, 2018). The BVS is 4.91 v.u. using the values of Brese \& O'Keeffe (1991) for calculation.

The crystal structure of $\mathrm{Zn}_{2}\left(\mathrm{HTeO}_{3}\right)\left(\mathrm{AsO}_{4}\right)$ is built up from $\infty_{\infty}^{2}\left[\mathrm{ZnO}_{3 / 2}(\mathrm{OH})_{1 / 2} \mathrm{O}_{1 / 1}\right]$ layers extending parallel to (001) (Fig. 3). The $\left[\mathrm{TeO}_{3} \mathrm{OH}\right]$ units are situated below a ${ }_{\infty}^{2}\left[\mathrm{ZnO}_{3 / 2}(\mathrm{OH})_{1 / 2} \mathrm{O}_{1 / 1}\right]$ layer and are isolated from each other. An individual $\left[\mathrm{TeO}_{3} \mathrm{OH}\right]$ unit shares three corners with two $\left[\mathrm{ZnO}_{4} \mathrm{OH}\right]$ polyhedra each, and one corner with an $\left[\mathrm{AsO}_{4}\right]$ tetrahedron. Likewise, the oxidoarsenate anions, situated above a ${ }_{\infty}^{2}\left[\mathrm{ZnO}_{3 / 2}(\mathrm{OH})_{1 / 2} \mathrm{O}_{1 / 1}\right]$ layer, are isolated from each other, but share corners with other building units: two corners with one $\left[\mathrm{ZnO}_{4} \mathrm{OH}\right]$ polyhedron each, one corner with two $\left[\mathrm{ZnO}_{4} \mathrm{OH}\right]$ polyhedra and one corner with a $\left[\mathrm{TeO}_{3} \mathrm{OH}\right]$ unit. This way, a three-dimensional framework structure is established (Fig. 4).

In the crystal structure, the spatial requirements of the $5 s^{2}$ electron lone pairs at the $\mathrm{Te}^{\mathrm{IV}}$ atoms lead to the formation of

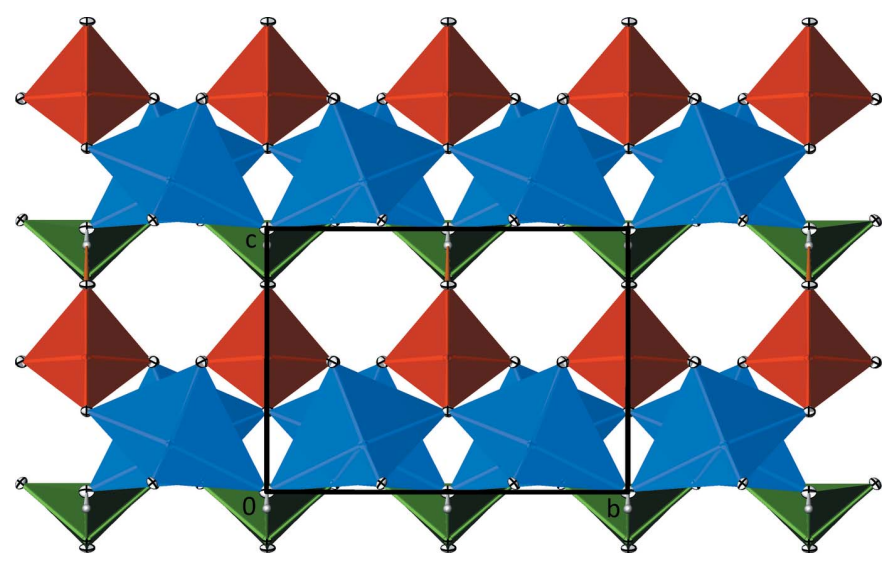

Figure 5

Channels in the structure of $\mathrm{Zn}_{2}\left(\mathrm{HTeO}_{3}\right)\left(\mathrm{AsO}_{4}\right)$ running parallel to [100]. Colour codes and displacement ellipsoids are as in Fig. 3. 
Table 3

Experimental details.

\begin{tabular}{|c|c|}
\hline \multicolumn{2}{|l|}{ Crystal data } \\
\hline Chemical formula & $\mathrm{Zn}_{2}\left(\mathrm{HTeO}_{3}\right)\left(\mathrm{AsO}_{4}\right)$ \\
\hline$M_{\mathrm{r}}$ & 446.27 \\
\hline Crystal system, space group & Monoclinic, $\mathrm{Cm}$ \\
\hline Temperature $(\mathrm{K})$ & 100 \\
\hline$a, b, c(\AA)$ & $6.9040(12), 7.7212(13), 5.726(1)$ \\
\hline$\beta\left(^{\circ}\right)$ & $101.196(5)$ \\
\hline$V\left(\AA^{3}\right)$ & $299.43(9)$ \\
\hline$Z$ & 2 \\
\hline Radiation type & Mo $K \alpha$ \\
\hline$\mu\left(\mathrm{mm}^{-1}\right)$ & 18.25 \\
\hline Crystal size $(\mathrm{mm})$ & $0.06 \times 0.04 \times 0.03$ \\
\hline \multicolumn{2}{|l|}{ Data collection } \\
\hline Diffractometer & Bruker APEXII CCD \\
\hline Absorption correction & $\begin{array}{l}\text { Multi-scan (SADABS; Krause et } \\
\quad \text { al., 2015) }\end{array}$ \\
\hline$T_{\min }, T_{\max }$ & $0.538,0.748$ \\
\hline $\begin{array}{l}\text { No. of measured, independent and } \\
\text { observed }[I>2 \sigma(I)] \text { reflections }\end{array}$ & $8261,1986,1918$ \\
\hline$R_{\text {int }}$ & 0.044 \\
\hline$(\sin \theta / \lambda)_{\max }\left(\AA^{-1}\right)$ & 0.915 \\
\hline \multicolumn{2}{|l|}{ Refinement } \\
\hline$R\left[F^{2}>2 \sigma\left(F^{2}\right)\right], w R\left(F^{2}\right), S$ & $0.019,0.040,0.92$ \\
\hline No. of reflections & 1986 \\
\hline No. of parameters & 63 \\
\hline No. of restraints & 2 \\
\hline $\mathrm{H}$-atom treatment & All $\mathrm{H}$-atom parameters refined \\
\hline$\Delta \rho_{\max }, \Delta \rho_{\min }\left(\mathrm{e} \AA^{-3}\right)$ & $1.79,-1.17$ \\
\hline Absolute structure & Refined as an inversion twin \\
\hline Absolute structure parameter & $0.032(12)$ \\
\hline
\end{tabular}

Computer programs: APEX3 and SAINT (Bruker, 2016), SHELXT (Sheldrick, 2015a), SHELXL (Sheldrick, 2015b), ATOMS for Windows (Dowty, 2006) and publCIF (Westrip, 2010).

channels parallel to [110] (Fig. 4). The weak O-H..O hydrogen bond is directed across these channels. There are also smaller channels oriented parallel to [100] that, however, remain empty (Fig. 5).

\section{Synthesis and crystallization}

Crystals of $\mathrm{Zn}_{2}\left(\mathrm{HTeO}_{3}\right)\left(\mathrm{AsO}_{4}\right)$ were obtained by hydrothermal synthesis. The reactants, $0.1949 \mathrm{~g}$ of $\mathrm{Zn}\left(\mathrm{NO}_{3}\right)_{2} \cdot 6 \mathrm{H}_{2} \mathrm{O}$ (0.670 mmol), $0.0512 \mathrm{~g}$ of $\mathrm{TeO}_{2}(0.321 \mathrm{mmol}), 0.1365 \mathrm{~g} 80 \%{ }_{\mathrm{wt}}$ of $\mathrm{H}_{3} \mathrm{AsO}_{4}$ (aq) $(0.713 \mathrm{mmol})$ and $0.22 \mathrm{~g}$ of $25 \%$ wt $\mathrm{NH}_{3}$ (aq) $(3.23 \mathrm{mmol})$ were weighed into a small Teflon vessel with an inner volume of $c a 3 \mathrm{ml}$. The vessel was filled with deionized water to three-quarters of its volume and the reactants were mixed by manual stirring. The Teflon vessel was then put into a steel autoclave and heated to $483 \mathrm{~K}$ for $7 \mathrm{~d}$ at autogenous pressure. Afterwards, the autoclave was cooled to room temperature within about $4 \mathrm{~h}$. The resulting product was a colourless multi-phase solid. In the $\mathrm{X}$-ray powder pattern of the bulk, $\mathrm{Zn}_{2}\left(\mathrm{HTeO}_{3}\right)\left(\mathrm{AsO}_{4}\right)$ was found as a by-product, in addition to $\left(\mathrm{NH}_{4}\right) \mathrm{Zn}\left(\mathrm{AsO}_{4}\right)$ (Feng et al., 2001) and the educt $\mathrm{TeO}_{2}\left(\alpha-\mathrm{TeO}_{2}\right.$; Stehlik \& Balak, 1948). Under a polarizing microscope, small colourless block-shaped crystals of $\mathrm{Zn}_{2}\left(\mathrm{HTeO}_{3}\right)\left(\mathrm{AsO}_{4}\right)$ were visible that were manually separated for the single-crystal $\mathrm{X}$-ray diffraction study.

\section{Refinement}

Crystal data, data collection and structure refinement details are summarized in Table 3. Atom labels and coordinates were standardized with Structure Tidy (Gelato \& Parthé, 1987) implemented in PLATON (Spek, 2020). The H atom of the hydroxy group was located in a difference-Fourier map and was refined freely. The crystal structure was refined under consideration of twinning by inversion, revealing a minor contribution of $3.2(12) \%$ for the inversion-related twin component.

\section{Acknowledgements}

The X-ray centre of the TU Wien is acknowledged for financial support and for providing access to the single-crystal and powder X-ray diffractometers.

\section{References}

Addison, A. W., Rao, N. T., Reedijk, J., van Rijn, J. \& Verschoor, G. C. (1984). J. Chem. Soc. Dalton Trans. pp. 1349-1356.

Binnewies, M., Glaum, R., Schmidt, M. \& Schmidt, P. (2012). Chemical Vapor Transport Reactions. Berlin: DeGruyter.

Brese, N. E. \& O'Keeffe, M. (1991). Acta Cryst. B47, 192-197.

Brown, I. D. (2002). The Chemical Bond in Inorganic Chemistry: The Bond Valence Model. Oxford University Press.

Bruker (2016). APEX3 and SAINT. Bruker AXS Inc., Madison, Wisconsin, USA.

Christy, A. G., Mills, S. J. \& Kampf, A. R. (2016). Miner. Mag. 80, 415545.

Dowty, E. (2006). ATOMS for Windows. Shape Software, Kingsport, Tennessee, USA.

Feng, P., Zhang, T. \& Bu, X. (2001). J. Am. Chem. Soc. 123, 86088609.

Gagné, O. C. \& Hawthorne, F. C. (2018). Acta Cryst. B74, 63-78.

Galy, J., Meunier, G., Andersson, S. \& Åström, A. (1975). J. Solid State Chem. 13, 142-159.

Gelato, L. M. \& Parthé, E. (1987). J. Appl. Cryst. 20, 139-143.

Hamani, D., Masson, O. \& Thomas, P. (2020). J. Appl. Cryst. 53, $1243-$ 1251.

Krause, L., Herbst-Irmer, R., Sheldrick, G. M. \& Stalke, D. (2015). J. Appl. Cryst. 48, 3-10.

Mills, S. J. \& Christy, A. G. (2013). Acta Cryst. B69, 145-149.

Missen, O. P., Weil, M., Mills, S. J. \& Libowitzky, E. (2020). Acta Cryst. B76, 1-6.

Ok, K. M., Chi, E. O. \& Halasyamani, P. S. (2006). Chem. Soc. Rev. 35, 710-717.

Schwendtner, K. \& Kolitsch, U. (2019). Acta Cryst. C75, 1134-1141.

Sheldrick, G. M. (2015a). Acta Cryst. A71, 3-8.

Sheldrick, G. M. (2015b). Acta Cryst. C71, 3-8.

Spek, A. L. (2020). Acta Cryst. E76, 1-11.

Stehlik, B. \& Balak, L. (1948). Chem. Zvesti, 2, 6-12.

Stöger, B. \& Weil, M. (2013). Miner. Petrol. 107, 253-263.

Weast, R. C. \& Astle, M. J. (1982). CRC Handbook of Chemistry and Physics, 63rd Edition, D-173. Boca Raton: CRC Press.

Weil, M. \& Shirkhanlou, M. (2017a). Z. Anorg. Allg. Chem. 643, 330339.

Weil, M. \& Shirkhanlou, M. (2017b). Z. Anorg. Allg. Chem. 643, 749756.

Weil, M. \& Shirkhanlou, M. (2017c). Z. Anorg. Allg. Chem. 643, 757765.

Westrip, S. P. (2010). J. Appl. Cryst. 43, 920-925.

Zimmermann, I., Kremer, R. K. \& Johnsson, M. (2011). J. Solid State Chem. 184, 3080-3084. 


\section{supporting information}

Acta Cryst. (2021). E77, 555-558 [https://doi.org/10.1107/S2056989021004333]

\section{Crystal structure of $\mathrm{Zn}_{2}\left(\mathrm{HTeO}_{3}\right)\left(\mathrm{AsO}_{4}\right)$}

\section{Felix Eder and Matthias Weil}

\section{Computing details}

Data collection: APEX3 (Bruker, 2016); cell refinement: SAINT (Bruker, 2016); data reduction: SAINT (Bruker, 2016); program(s) used to solve structure: SHELXT (Sheldrick, 2015a); program(s) used to refine structure: SHELXL (Sheldrick, 2015b); molecular graphics: ATOMS for Windows (Dowty, 2006); software used to prepare material for publication: publCIF (Westrip, 2010).

Dizinc(II) hydroxidodioxidotellurate(IV) oxidoarsenate(V)

Crystal data

$\mathrm{Zn}_{2}\left(\mathrm{HTeO}_{3}\right)\left(\mathrm{AsO}_{4}\right)$

$M_{r}=446.27$

Monoclinic, $\mathrm{Cm}$

$a=6.9040(12) \AA$

$b=7.7212(13) \AA$

$c=5.726(1) \AA$

$\beta=101.196(5)^{\circ}$

$V=299.43(9) \AA^{3}$

$Z=2$

Data collection

Bruker APEXII CCD

diffractometer

$\omega$ - and $\varphi$-scans

Absorption correction: multi-scan

(SADABS; Krause et al., 2015)

$T_{\min }=0.538, T_{\max }=0.748$

8261 measured reflections

\section{Refinement}

Refinement on $F^{2}$

Least-squares matrix: full

$R\left[F^{2}>2 \sigma\left(F^{2}\right)\right]=0.019$

$w R\left(F^{2}\right)=0.040$

$S=0.92$

1986 reflections

63 parameters

2 restraints

Hydrogen site location: difference Fourier map

All $\mathrm{H}$-atom parameters refined
$F(000)=404$

$D_{\mathrm{x}}=4.950 \mathrm{Mg} \mathrm{m}^{-3}$

Mo $K \alpha$ radiation, $\lambda=0.71073 \AA$

Cell parameters from 5391 reflections

$\theta=3.6-40.6^{\circ}$

$\mu=18.25 \mathrm{~mm}^{-1}$

$T=100 \mathrm{~K}$

Block, colourless

$0.06 \times 0.04 \times 0.03 \mathrm{~mm}$

1986 independent reflections

1918 reflections with $I>2 \sigma(I)$

$R_{\text {int }}=0.044$

$\theta_{\max }=40.6^{\circ}, \theta_{\min }=3.6^{\circ}$

$h=-12 \rightarrow 12$

$k=-14 \rightarrow 14$

$l=-10 \rightarrow 10$

$w=1 /\left[\sigma^{2}\left(F_{\mathrm{o}}^{2}\right)\right]$

where $P=\left(F_{\mathrm{o}}{ }^{2}+2 F_{\mathrm{c}}{ }^{2}\right) / 3$

$(\Delta / \sigma)_{\max }<0.001$

$\Delta \rho_{\max }=1.79$ e $\AA^{-3}$

$\Delta \rho_{\min }=-1.16$ e $\AA^{-3}$

Extinction correction: SHELXL (Sheldrick, 2015b), $\mathrm{Fc}^{*}=\mathrm{kFc}\left[1+0.001 \mathrm{xFc}^{2} \lambda^{3} / \sin (2 \theta)\right]^{-1 / 4}$

Extinction coefficient: 0.0043 (5)

Absolute structure: Refined as an inversion twin

Absolute structure parameter: 0.032 (12) 


\section{Special details}

Geometry. All esds (except the esd in the dihedral angle between two 1.s. planes) are estimated using the full covariance matrix. The cell esds are taken into account individually in the estimation of esds in distances, angles and torsion angles; correlations between esds in cell parameters are only used when they are defined by crystal symmetry. An approximate (isotropic) treatment of cell esds is used for estimating esds involving l.s. planes.

Refinement. Refined as a two-component inversion twin.

Fractional atomic coordinates and isotropic or equivalent isotropic displacement parameters $\left(\AA^{2}\right)$

\begin{tabular}{lllll}
\hline & $x$ & $y$ & $z$ & $U_{\text {iso }}^{*} / U_{\text {eq }}$ \\
\hline Te1 & $0.70945(3)$ & 0.000000 & $0.81776(3)$ & $0.00418(6)$ \\
As1 & $0.24451(6)$ & 0.000000 & $0.51174(7)$ & $0.00440(9)$ \\
Zn1 & $0.46889(7)$ & $0.23359(4)$ & $0.17917(8)$ & $0.00521(7)$ \\
O1 & $0.1089(4)$ & $0.1808(3)$ & $0.4941(4)$ & $0.0081(4)$ \\
O2 & $0.1998(4)$ & $0.3177(3)$ & $0.0329(4)$ & $0.0062(4)$ \\
O3 & $-0.0007(6)$ & 0.000000 & $0.0002(6)$ & $0.0087(6)$ \\
O4 & $0.3941(5)$ & 0.000000 & $0.3064(6)$ & $0.0063(5)$ \\
O5 & $0.3968(5)$ & 0.000000 & $0.7868(6)$ & $0.0065(5)$ \\
H1 & $0.114(13)$ & 0.000000 & $-0.064(14)$ & $0.015(19)^{*}$ \\
\hline
\end{tabular}

Atomic displacement parameters $\left(\AA^{2}\right)$

\begin{tabular}{lllllll}
\hline & $U^{11}$ & $U^{22}$ & $U^{33}$ & $U^{12}$ & $U^{13}$ & $U^{23}$ \\
\hline Te1 & $0.00465(12)$ & $0.00392(11)$ & $0.00381(11)$ & 0.000 & $0.00040(8)$ & 0.000 \\
As1 & $0.0040(2)$ & $0.0047(2)$ & $0.00427(18)$ & 0.000 & $0.00031(16)$ & 0.000 \\
Zn1 & $0.00389(15)$ & $0.00549(13)$ & $0.00595(15)$ & $0.00021(15)$ & $0.00023(11)$ & $0.00043(13)$ \\
O1 & $0.0090(10)$ & $0.0078(10)$ & $0.0068(9)$ & $0.0039(8)$ & $-0.0006(8)$ & $-0.0004(7)$ \\
O2 & $0.0061(9)$ & $0.0058(9)$ & $0.0068(9)$ & $0.0000(8)$ & $0.0015(7)$ & $0.0021(7)$ \\
O3 & $0.0055(14)$ & $0.0116(14)$ & $0.0085(13)$ & 0.000 & $0.0001(11)$ & 0.000 \\
O4 & $0.0067(14)$ & $0.0064(13)$ & $0.0062(12)$ & 0.000 & $0.0025(11)$ & 0.000 \\
O5 & $0.0049(13)$ & $0.0103(14)$ & $0.0041(11)$ & 0.000 & $0.0001(10)$ & 0.000 \\
\hline
\end{tabular}

Geometric parameters $\left(\AA,{ }^{\circ}\right)$

\begin{tabular}{|c|c|c|c|}
\hline $\mathrm{Te} 1-\mathrm{O} 2^{\mathrm{i}}$ & $1.880(2)$ & As $1-\mathrm{O} 5$ & $1.716(3)$ \\
\hline $\mathrm{Te} 1-\mathrm{O} 2^{\mathrm{ii}}$ & $1.880(2)$ & $\mathrm{Zn} 1-\mathrm{O} 2^{\mathrm{v}}$ & $1.979(3)$ \\
\hline $\mathrm{Te} 1-\mathrm{O} 3^{\mathrm{iii}}$ & $2.070(4)$ & $\mathrm{Zn} 1-\mathrm{O}^{\mathrm{v}}$ & $1.987(3)$ \\
\hline $\mathrm{Te} 1-\mathrm{O} 5$ & $2.131(4)$ & $\mathrm{Zn} 1-\mathrm{O} 2$ & $1.993(3)$ \\
\hline As $1-O 1^{\text {iv }}$ & $1.673(2)$ & $\mathrm{Zn} 1-\mathrm{O} 4$ & $2.0486(16)$ \\
\hline As $1-\mathrm{O} 1$ & $1.673(2)$ & $\mathrm{Zn} 1-\mathrm{O}^{\mathrm{vi}}$ & $2.3259(18)$ \\
\hline As $1-\mathrm{O} 4$ & $1.709(3)$ & $\mathrm{O} 3-\mathrm{H} 1$ & $0.94(9)$ \\
\hline $\mathrm{O} 2^{\mathrm{i}}-\mathrm{Te} 1-\mathrm{O} 2^{\mathrm{ii}}$ & $96.96(14)$ & $\mathrm{O} 2^{\mathrm{v}}-\mathrm{Zn} 1-\mathrm{O}^{\mathrm{vi}}$ & $80.87(12)$ \\
\hline $\mathrm{O} 2^{\mathrm{i}}-\mathrm{Te} 1-\mathrm{O} 3^{\mathrm{iii}}$ & $79.82(10)$ & $\mathrm{O} 1^{\mathrm{v}}-\mathrm{Zn} 1-\mathrm{O} 3^{\mathrm{vi}}$ & $92.08(11)$ \\
\hline $\mathrm{O} 2^{\mathrm{ii}}-\mathrm{Te} 1-\mathrm{O} 3^{\mathrm{iii}}$ & $79.82(10)$ & $\mathrm{O} 2-\mathrm{Zn} 1-\mathrm{O}^{\mathrm{vi}}$ & $71.53(12)$ \\
\hline $\mathrm{O} 2 \mathrm{i}-\mathrm{Te} 1-\mathrm{O} 5$ & $83.70(10)$ & $\mathrm{O} 4-\mathrm{Zn} 1-\mathrm{O}^{\mathrm{vi}}$ & $170.38(14)$ \\
\hline $\mathrm{O} 22^{\mathrm{ii}}-\mathrm{Te} 1-\mathrm{O} 5$ & $83.70(10)$ & As1-O1-Zn1 vii & $120.01(13)$ \\
\hline $\mathrm{O} 3{ }^{\mathrm{iii}-\mathrm{Te} 1-\mathrm{O} 5}$ & $155.01(13)$ & $\mathrm{Te} 1^{\mathrm{viii}}-\mathrm{O} 2-\mathrm{Zn} 1^{\mathrm{vii}}$ & $124.12(13)$ \\
\hline
\end{tabular}




\begin{tabular}{|c|c|c|c|}
\hline $\mathrm{O} 1^{\mathrm{iv}}-\mathrm{As} 1-\mathrm{O} 1$ & $113.14(19)$ & $\mathrm{Te} 1^{\mathrm{vii}}-\mathrm{O} 2-\mathrm{Zn} 1$ & $111.74(13)$ \\
\hline $\mathrm{O} 1^{\mathrm{iv}}-\mathrm{As} 1-\mathrm{O} 4$ & $111.36(10)$ & $\mathrm{Zn} 1^{\mathrm{vii}}-\mathrm{O} 2-\mathrm{Zn} 1$ & $121.25(11)$ \\
\hline $\mathrm{O} 1-\mathrm{As} 1-\mathrm{O} 4$ & $111.36(10)$ & $\mathrm{Te} 1^{\mathrm{ix}}-\mathrm{O} 3-\mathrm{Zn} 1^{\mathrm{vii}}$ & $93.51(11)$ \\
\hline $\mathrm{O}^{\mathrm{iv}}-\mathrm{As} 1-\mathrm{O} 5$ & $106.93(11)$ & $\mathrm{Te} 1^{\mathrm{ix}}-\mathrm{O} 3-\mathrm{Zn} 1^{\mathrm{x}}$ & $93.51(11)$ \\
\hline $\mathrm{O} 1-\mathrm{As} 1-\mathrm{O} 5$ & $106.93(11)$ & $\mathrm{Zn} 1^{\mathrm{vii}}-\mathrm{O} 3-\mathrm{Zn} 1^{\mathrm{x}}$ & $124.36(16)$ \\
\hline $\mathrm{O} 4-\mathrm{As} 1-\mathrm{O} 5$ & $106.69(17)$ & $\mathrm{Te} 1^{\mathrm{ix}}-\mathrm{O} 3-\mathrm{H} 1$ & $128(5)$ \\
\hline $\mathrm{O} 2^{\mathrm{v}}-\mathrm{Zn} 1-\mathrm{O} 1^{\mathrm{v}}$ & $99.25(11)$ & $\mathrm{Zn} 1^{\mathrm{vii}}-\mathrm{O} 3-\mathrm{H} 1$ & $109.1(18)$ \\
\hline $\mathrm{O} 2^{\mathrm{v}}-\mathrm{Zn} 1-\mathrm{O} 2$ & $130.47(12)$ & $\mathrm{Zn} 1{ }^{\mathrm{x}}-\mathrm{O} 3-\mathrm{H} 1$ & $109.1(18)$ \\
\hline $\mathrm{O} 1^{\mathrm{v}}-\mathrm{Zn} 1-\mathrm{O} 2$ & $121.53(11)$ & As1-O4-Zn1 & $118.20(8)$ \\
\hline $\mathrm{O} 2^{\mathrm{v}}-\mathrm{Zn} 1-\mathrm{O} 4$ & $104.71(11)$ & $\mathrm{As} 1-\mathrm{O} 4-\mathrm{Zn} 1^{\mathrm{iv}}$ & $118.20(8)$ \\
\hline $\mathrm{O} 1^{\mathrm{v}}-\mathrm{Zn} 1-\mathrm{O} 4$ & $94.69(11)$ & $\mathrm{Zn} 1-\mathrm{O} 4-\mathrm{Zn} 1^{\mathrm{iv}}$ & $123.38(16)$ \\
\hline $\mathrm{O} 2-\mathrm{Zn} 1-\mathrm{O} 4$ & $99.06(12)$ & As $1-\mathrm{O} 5-\mathrm{Te} 1$ & $120.43(18)$ \\
\hline
\end{tabular}

Symmetry codes: (i) $x+1 / 2,-y+1 / 2, z+1$; (ii) $x+1 / 2, y-1 / 2, z+1$; (iii) $x+1, y, z+1$; (iv) $x,-y, z$; (v) $x+1 / 2,-y+1 / 2, z$; (vi) $x+1 / 2, y+1 / 2, z$; (vii) $x-1 / 2$, $-y+1 / 2, z$; (viii) $x-1 / 2, y+1 / 2, z-1$; (ix) $x-1, y, z-1$; (x) $x-1 / 2, y-1 / 2, z$.

Hydrogen-bond geometry $\left(A,{ }^{\circ}\right)$

\begin{tabular}{lllll}
\hline$D-\mathrm{H} \cdots A$ & $D-\mathrm{H}$ & $\mathrm{H} \cdots A$ & $D \cdots A$ & $D-\mathrm{H} \cdots A$ \\
\hline $\mathrm{O} 3-\mathrm{H} 1 \cdots 5^{\mathrm{xi}}$ & $0.94(9)$ & $2.28(9)$ & $3.213(5)$ & $179(7)$ \\
\hline
\end{tabular}

Symmetry code: (xi) $x, y, z-1$. 